Acta vet. scand. $1977,18,23-30$.

From the Department of Food Hygiene and the Research Station for Furbearing Animals, Veterinary College of Norway, Oslo, and the Norwegian Fur Farmers Research Laboratory, Oslo, Norway.

\title{
SUSCEPTIBILITY OF FOXES TO CLOSTRIDIUM BOTULINUM TYPE C AND E TOXINS
}

By

Magne Yndestad, Arne Helgebostad and Gudbrand Loftsgård

YNDESTAD, MAGNE, ARNE HELGEBOSTAD and GUDBRAND LOFTSGARD: Susceptibility of foxes to Clostridium botulinum type $C$ and $E$ toxins. Acta vet. scand. 1977, 18, 23-30. - Investigations were performed to determine the exact susceptibility of foxes to Clostridium botulinum type $\mathrm{C}$ and $\mathrm{E}$ toxins.

Doses of 5 mill. MLD type $C$ toxin mixed with the feed did not cause symptoms of botulism in either cubs or adult foxes. Subcutaneous injections of 300,000 MLD or more were fatal to cubs, while 750,000 MLD caused the death of all adults.

Regarding type $\mathrm{E}$ toxin, doses of 1 mill. MLD affected neither cubs nor adults on oral administration. Subcutaneously injected doses of 5,000 MLD or more killed all cubs, while 10,000 MLD was required to produce lethal effect on adult animals.

The conclusion made is that foxes are highly resistant to both type $\mathrm{C}$ and $\mathrm{E}$ Clostridium botulinum toxins following oral application. It is further revealed that foxes are $60-70$ times more susceptible to type $E$ than to type $C$ toxin when injected subcutaneously.

susceptibility; Glostridium botulinum toxin; fox.

Foxes are generally considered to be highly resistant to Clostridium botulinum toxins. This assumption is supported by the fact that very few outbreaks of feed poisoning in fox farms are caused by botulinum toxin, while botulism in mink has been reported by many workers (Hall \& Stiles 1938, Quortrup \& Holt 1940, Kennedy 1946, Dinter \& Kull 1950, 1955, Kull \& Moberg 1952, Skulberg 1957, 1961, Gustavsen et al. 1969).

There is, however, some discrepancy in the literature concerning the tolerance of foxes to different types of Clostridium botulinum toxins. Pyle \& Brown (1939) reported that Clostridium botulinum type A caused the death of silver foxes fed canned fish. Quortrup \& Gorham (1949) found that foxes were immune 
to type A, B and C botulinum toxins on oral administration. Nearly 190 blue foxes died of intoxication on a Norwegian farm. In this case Nordstoga (1973) demonstrated type C toxin in the feed, but did not succeed in causing botulism by feeding foxes with the suspected material.

The experiments reported in this paper were performed to obtain further information on the susceptibility of foxes to type $\mathrm{C}$ and $\mathrm{E}$ toxins. These toxins are most frequently found in outbreaks of botulism in mink (type $\mathrm{C}$ ) and man (type E) in Norway.

\section{MATERIALS AND METHODS}

Type $\mathrm{C}$ toxin was produced by a Clostridium botulinum Nerz strain. This toxin has proved to be highly toxic to mink (Yndestad \& Loftsgård 1970). Clostridium botulinum strain No. 8-OT was used for type $\mathrm{E}$ toxin production. The production of toxins was performed as reported by Tjaberg \& Skulberg (1968).

The toxin activity was determined by intraperitoneal injection on mice weighing $18-20 \mathrm{~g}$ with serial dilutions (MLD-determination). The stock solution of type $\mathrm{C}$ toxin was thus found to contain $8 \times 10^{5}$ MLD per ml. Similarly, the type $\mathrm{E}$ toxin was found to contain $2 \times 10^{5} \mathrm{MLD}$ per ml after activation with $0.1 \%$ trypsin (Difco 1:250). Standard toxin dilutions were then prepared and immediately frozen in glass vials. These were stored at $-25^{\circ} \mathrm{C}$, and each vial was thawed immediately before use. Control titrations of the toxins were performed during the course of the experiment. No change in toxicity was observed.

Blue fox cubs and adult foxes of both sexes were used as test animals. They were divided into 2 main groups; one receiving type $\mathrm{C}$ toxin, the other type $\mathrm{E}$ toxin. These groups were further divided into subgroups consisting of cubs and adult animals. Approximately half of the subgroups received the toxin mixed with a lesser portion of the diet (to secure complete intake), the other half by subcutaneous injection in the axillary region. Foxes developing symptoms of botulism were observed until either recovery or death occurred.

\section{RESULTS}

Results from the susceptibility test with type $\mathrm{C}$ toxin on blue foxes are shown in Tables 1 and 2. Similarly, Tables 3 and 4 show the susceptibility to type $\mathrm{E}$ toxin. 
T a b l e 1. Experiments in cubs with peroral and subcutaneous administration of Clostridium botulinum type $\mathrm{C}$ toxin.

\begin{tabular}{|c|c|c|c|c|c|c|c|c|c|c|}
\hline \multirow{2}{*}{$\begin{array}{c}\text { Fox } \\
\text { no. }\end{array}$} & \multirow{2}{*}{$\begin{array}{c}\text { Weight } \\
\text { kg }\end{array}$} & \multirow[b]{2}{*}{ MLD } & \multicolumn{2}{|c|}{ Administration } & \multicolumn{6}{|c|}{ Symptoms } \\
\hline & & & peroral & $\begin{array}{c}\text { sub- } \\
\text { cutaneous }\end{array}$ & 1. day & 2. day & 3. day & 4. day & 5. day & $\begin{array}{l}\text { 6. day } \\
\text { or more }\end{array}$ \\
\hline 1 & 1.5 & 500,000 & $x$ & & - & - & - & - & - & - \\
\hline 2 & 1.4 & 1 mill. & $x$ & & - & - & - & - & - & - \\
\hline 3 & 1.5 & 1 mill. & $x$ & & - & - & - & - & - & - \\
\hline 4 & 1.5 & 5 mill. & $x$ & & - & - & - & - & - & - \\
\hline 5 & 1.3 & 5 mill. & $x$ & & - & - & - & - & - & - \\
\hline 6 & 1.2 & 1,000 & & $x$ & - & - & - & - & - & - \\
\hline 7 & 1.2 & 10,000 & & $x$ & - & - & - & - & - & - \\
\hline 8 & 1.5 & 25,000 & & $x$ & - & 一 & - & - & - & - \\
\hline 9 & 1.5 & 25,000 & & $x$ & - & 一 & - & - & - & - \\
\hline 10 & 1.5 & 50,000 & & $x$ & - & - & - & - & - & - \\
\hline 11 & 1.5 & 50,000 & & $x$ & 一 & - & + & $\mathbf{R}$ & - & - \\
\hline 12 & 1.2 & 100,000 & & $x$ & - & + & ++ & + & $\mathbf{R}$ & - \\
\hline 13 & 1.5 & 100,000 & & $x$ & + & ++ & ++ & + & $\mathbf{R}$ & - \\
\hline 14 & 2.5 & 200,000 & & $x$ & - & + & + & + & $\mathbf{R}$ & - \\
\hline 15 & 2.5 & $200 ; 000$ & & $x$ & + & + & + & + & + & $\mathbf{R}$ \\
\hline 16 & 2.0 & 300,000 & & & + & ++ & D & & & \\
\hline 17 & 2.2 & 300,000 & & $x$ & + & ++ & ++ & D & & \\
\hline 18 & 2.0 & 400,000 & & $x$ & $+t$ & D & & & & \\
\hline 19 & 1.2 & 500,000 & & $x$ & D & & & & & \\
\hline
\end{tabular}

Explanation of symbols:

MLD $=$ Mouse lethal doses.

- = No symptoms of disease.

$+\quad=$ Vague symptoms of botulism.

$++=$ Typical symptoms of botulism.

$\mathrm{D}=$ Dead.

$\mathbf{R}=$ Complete recovery.

Type $C$ toxin, oral and subcutaneous administration

It can be seen in Table 1 that blue fox cubs did not develop symptoms of botulism when given oral doses of up to 5 mill. MLD. Cubs receiving 100,000 MLD s.c. developed typical symptoms of botulism but recovered, while 300,000 MLD or more caused the death of all animals.

Adult foxes showed no signs of botulism following oral administration of doses up to 5 mill. MLD. Subcutaneous injections of 500,000 MLD caused typical signs of botulism, while 750,000 MLD or more killed adult foxes. One adult fox given $\mathbf{1 0 0 , 0 0 0}$ MLD also died (Table 2). 
Table 2. Experiments in adult foxes with peroral and subcutaneous administration of Clostridium botulinum type $\mathrm{C}$ toxin.

\begin{tabular}{|c|c|c|c|c|c|c|c|c|c|c|}
\hline \multirow{2}{*}{$\begin{array}{l}\text { Fox } \\
\text { no. }\end{array}$} & \multirow{2}{*}{$\begin{array}{c}\text { Weight } \\
\text { kg }\end{array}$} & \multirow[b]{2}{*}{ MLD } & \multicolumn{2}{|c|}{ Administration } & \multicolumn{6}{|c|}{ Symptoms } \\
\hline & & & peroral & $\begin{array}{c}\text { sub- } \\
\text { cutaneous }\end{array}$ & 1. day & 2. day & 3. day & 4. day & 5. day & $\begin{array}{l}\text { 6. day } \\
\text { or more }\end{array}$ \\
\hline 20 & 4.5 & 500,000 & $x$ & & - & - & - & - & - & - \\
\hline 21 & 4.0 & 1 mill. & $x$ & & - & - & - & - & - & - \\
\hline 22 & 4.8 & 1 mill. & $x$ & & - & - & - & - & - & - \\
\hline 23 & 5.0 & 5 mill. & $x$ & & - & - & - & - & - & - \\
\hline 24 & 4.5 & 5 mill. & $x$ & & - & - & - & - & - & - \\
\hline 25 & 4.4 & 1,000 & & $x$ & - & - & - & - & - & - \\
\hline 26 & 4.7 & 10,000 & & $x$ & - & - & - & - & - & - \\
\hline 27 & 5.0 & 100,000 & & $x$ & - & - & - & - & - & - \\
\hline 28 & 4.1 & 100,000 & & $x$ & - & + & D & & & \\
\hline 29 & 7.9 & 250,000 & & $x$ & - & - & - & - & - & - \\
\hline 30 & 7.4 & 250,000 & & $x$ & - & - & - & - & - & - \\
\hline 31 & 7.5 & 500,000 & & $x$ & - & + & + & + & + & $\mathbf{R}$ \\
\hline 32 & 8.4 & 500,000 & & $x$ & - & - & + & + & + & $\mathbf{R}$ \\
\hline 33 & 7.9 & 750,000 & & $x$ & - & ++ & D & & & \\
\hline 34 & 8.2 & 750,000 & & $x$ & + & + & D & & & \\
\hline 35 & 5.4 & 1 mill. & & $x$ & + & D & & & & \\
\hline 36 & 7.7 & 1 mill. & & $x$ & ++ & D & & & & \\
\hline
\end{tabular}

For explanation of symbols see Table 1 .

Type E toxin, oral and subcutaneous administration

No symptoms of botulism occurred when blue fox cubs received up to 1 mill. MLD type $E$ toxin orally. Subcutaneously injected doses of 500 MLD caused vague symptoms of botulism, and 5000 MLD or more killed all cubs (Table 3).

Similar results were obtained using adult foxes. In this group, doses of 1 mill. MLD type $E$ toxin in the feed did not affect the animals. Foxes receiving 5000 MLD by parenteral application developed mild symptoms of botulism, while 10,000 or more killed all animals in the group (Table 4 ).

\section{DISCUSSION}

The present investigation shows that foxes are extremely resistant to Clostridium botulinum toxin type $\mathrm{C}$ administered orally, as doses of up to 5 mill. MLD did not affect the animals. This is in agreement with the results of Quortrup \& Gorham (1949) and practical observations. 
T a b l e 3. Experiments in cubs with peroral and subcutaneous administration of Clostridium botulinum type $\mathrm{E}$ toxin.

\begin{tabular}{|c|c|c|c|c|c|c|c|c|c|c|}
\hline \multirow{2}{*}{$\begin{array}{l}\text { Fox } \\
\text { no. }\end{array}$} & \multirow{2}{*}{$\begin{array}{c}\text { Weight } \\
\mathrm{kg}\end{array}$} & \multirow[b]{2}{*}{ MLD } & \multicolumn{2}{|c|}{ Administration } & \multicolumn{6}{|c|}{ Symptoms } \\
\hline & & & peroral & $\begin{array}{c}\text { sub- } \\
\text { cutaneous }\end{array}$ & 1. day & 2. day & 3. day & 4. day & 5. day & $\begin{array}{l}\text { 6. day } \\
\text { or more }\end{array}$ \\
\hline 37 & 2.5 & 50,000 & $x$ & & - & - & - & - & - & - \\
\hline 38 & 2.5 & 100,000 & $x$ & & - & - & - & - & - & - \\
\hline 39 & 2.5 & 500,000 & $x$ & & - & 一 & - & - & - & - \\
\hline 40 & 2.4 & 1 mill. & $x$ & & - & - & - & - & - & - \\
\hline 41 & 2.0 & 100 & & $x$ & - & - & - & - & - & - \\
\hline 42 & 2.0 & 500 & & $x$ & - & + & + & $\mathbf{R}$ & & \\
\hline 43 & 2.0 & 1,000 & & $x$ & + & + & + & $\mathbf{R}$ & & \\
\hline 44 & 2.1 & 5,000 & & $x$ & + & ++ & ++ & ++ & ++ & D \\
\hline 45 & 2.4 & 10,000 & & $x$ & ++ & D & & & & \\
\hline 46 & 2.0 & 25,000 & & $x$ & ++ & D & & & & \\
\hline 47 & 2.6 & 50,000 & & $x$ & D & & & & & \\
\hline
\end{tabular}

For explanation of symbols see Table 1.

T a b l e 4. Experiments in adult foxes with peroral and subcutaneous administration of Clostridium botulinum type E toxin.

\begin{tabular}{|c|c|c|c|c|c|c|c|c|c|c|}
\hline \multirow{2}{*}{$\begin{array}{c}\text { Fox } \\
\text { no. }\end{array}$} & \multirow{2}{*}{$\begin{array}{c}\text { Weight } \\
\text { kg }\end{array}$} & \multirow[b]{2}{*}{ MLD } & \multicolumn{2}{|c|}{ Administration } & \multicolumn{6}{|c|}{ Symptoms } \\
\hline & & & peroral & $\begin{array}{c}\text { sub- } \\
\text { cutaneous }\end{array}$ & 1. day & 2. day & 3. day & 4. day & 5. day & $\begin{array}{l}\text { 6. day } \\
\text { or more }\end{array}$ \\
\hline 48 & 7.2 & 50,000 & $x$ & & - & - & 一 & - & 一 & - \\
\hline 49 & 6.8 & 100,000 & $x$ & & - & - & - & - & 一 & - \\
\hline 50 & 6.7 & 500,000 & $x$ & & - & - & - & - & - & - \\
\hline 51 & 6.7 & 1 mill. & $x$ & & - & - & - & - & - & - \\
\hline 52 & 6.4 & 500 & & $x$ & - & - & - & - & - & - \\
\hline 53 & 6.4 & 1,000 & & $x$ & - & - & - & - & - & - \\
\hline 54 & 8.0 & 5,000 & & $x$ & 一 & + & + & $\mathbf{R}$ & & \\
\hline 55 & 7.5 & 10,000 & & $x$ & + & D & & & & \\
\hline 56 & 7.6 & 25,000 & & $x$ & D & & & & & \\
\hline 57 & 7.7 & 50.000 & & $x$ & D & & & & & \\
\hline 58 & 7.7 & 100,000 & & $x$ & D & & & & & \\
\hline 59 & 6.9 & 200,000 & & $x$ & D & & & & & \\
\hline
\end{tabular}

For explanation of symbols see Table 1 .

The results also indicate that the lethal dose following subcutaneous injection is rather high; exceeding 300,000 MLD for cubs and 750,000 for adults. Calculated on the basis of body weight, the lethal dose is about 100-150 MLD per g. In compari- 
son, Dinter \& Kull (1955) and Yndestad \& Loftsgård (1970) reported lethal doses of 0.07 MLD and 0.04 MLD per g body weight respectively following parenteral application in mink.

The foxes seem to be resistant to type $\mathrm{E}$ toxin as well, as no symptoms of botulism could be observed after intake of 1 mill. MLD. It was desirable to expose the animals to higher doses, but the experiment had to be terminated as the foxes refused the feed containing larger amounts of type $\mathrm{E}$ toxin. Application by tube directly into the stomach was not tried.

Following subcutaneous injection of type $\mathrm{E}$ toxin into cubs, doses of 5000 MLD or more killed all the animals. Adult foxes died after the application of 10,000 MLD or more. Calculated on the basis of body weight, the lethal dose would be 1.4-2.5 MLD per $\mathrm{g}$. This indicates that the susceptibility of foxes to type $\mathrm{E}$ toxin is $60-70$ times greater than to type $\mathrm{C}$ toxin when given subcutaneously.

The differences in the oral and parenteral susceptibility of foxes to Clostridium botulinum toxin found in these experiments are also known from other species. Graham \& Erikson (1922), Legroux \& Levaditi (1947) and Vallée et al. (1956) stated that dogs were susceptible to different botulinum toxins by parenteral but not by oral application. Natural, or spontaneous, outbreaks of botulism in dogs have, however, been described (Vallée et al., Johannsen 1965).

Cats are highly resistant to different Clostridium botulinum toxins, but succumb rapidly after parenteral injection of small amounts of these toxins (Skulberg, personal communication 1976).

Tjaberg \& Skulberg (1968) and Yndestad \& Loftsgård found that Clostridium botulinum type $\mathrm{C}$ toxin in mink was about 40 and 20 times, respectively, more potent when administered subcutaneously as compared to oral administration. Skulberg \& Valland (1969) found that type $\mathrm{E}$ toxin was approx. 100 times more potent when injected subcutaneously into mink as compared to feeding.

As mentioned earlier, our investigation also shows that foxes are 60-70 times more susceptible to type $E$ than to type $C$ toxin following parenteral application. This difference in susceptibility to the different types of Clostridium botulinum toxins has been registered in mink for example. Quortrup \& Gorham found that mink was moderately susceptible to Clostridium botulinum type 
$A$ and $B$ and highly susceptible to type $C$ on oral administration. Dinter \& Kull (1955) observed that type A toxin was about 400 times less toxic when fed to mink compared to type C toxin. Skulberg \& Valland showed that mink were approx. 25 times more susceptible to type $\mathrm{C}$ than to type $\mathrm{E}$ toxin after oral administration.

Many authors have discussed the difference in susceptibility for oral and parenteral administration of Clostridium botulinum toxin, as well as the variation in toxicity of different botulinal toxins in the same species, but without reaching any definite conclusions. Further experimental work should, therefore, be devoted to these problems.

\section{REFERENCES}

Dinter, Z. \& K. E. Kull: Botulismus beim Nerz in Schweden. (Botulism in mink in Sweden). Nord. Vet.-Med. 1950, 2, 286-301.

Dinter, Z. \& K. E. Kull: Über die Empfänglichkeit des Nerzes für die Botulinus-Toxine A und C. (The susceptibility of mink to botulinum toxins A and C). Nord. Vet.-Med. 1955, 7, 549-5613.

Graham, R. \& S. Erikson: Experimental botulism in dogs. J. infect. Dis. 1922, 31, 402-4.06.

Gustavsen, S., S. Hauge, G. Loftsgård, T. Oftebro, L. Rosseb $\varnothing$, T. B. Tjaberg \& T. Aaneland: Repeated botulism outbreaks in mink caused by feed from a central processing plant. Canad. vet. J. $1969,10,244-247$.

Hall, I. C. \& G. W. Stiles: An outbreak of botulism in captive mink on a furfarm in Colorado. J. Bact. 1938, 36, 282.

Johannsen, A.: Botulisme hos hund. (Botulism in dogs). Nord. Vet.Med. 1965, 17, 680—684.

Kennedy, A. H.: Mink and fox diseases in Ontario. Rep. Ontario Vet. Coll., Toronto, Canada 1946, 47, 98-105.

Kull, K. E. \& K. Moberg: Die Häufigkeit des Botulismus bei Füttervergiftungen des Nerzes in Schweden 1951. (The frequency of food poisonings caused by botulism in minks in Sweden in 1951). Nord. Vet.-Med. 1952, 4, 771-775.

Legroux, E. \& J. C. Levaditi: Le botulisme experimental du chien et la question du botulisme naturelle. (Experimental and possible naturally occurring botulism in dogs). Ann. Inst. Pasteur 1947, 73, 105—115.

Nordstoga, K.: Mistanke om botulisme i en blårevbesetning. (Suspected occurrence of botulism in a blue fox farm). Norsk Vet.-T. 1973, $85,654-655$.

Pyle, N. J. \& R. M. Brown: Botulism in foxes. J. Amer. vet. med. Ass. $1939,94,436-439$. 
Quortrup, E. R. \& J. R. Gorham: Susceptibility of furbearing animals to the toxins of Clostridium botulinum types A, B, C and E. Amer. J. vet. Res. 1949, 10, 268-271.

Quortrup, E. R. \& A. L. Holt: A case report on botulism type C in mink. J. Amer. vet. med. Ass. 1940, 97, 167-168.

Skulberg, A.: Botulisme hos mink. (Botulism in mink). Medlemsbl. norske Vet.-Foren. 1957, 9, 41-48.

Skulberg, A.: Botulism in mink caused by Clostridium botulinum type E. Nord. Vet.-Med. 1961, 13, 87-95.

Skulberg, A. \& M. Valland: Susceptibility of mink to Clostridium botulinum type $\mathrm{E}$ toxin. Acta vet. scand. 1969, 10, 137-145.

Tjaberg, T. B. \& A. Skulberg: Minks mottagelighet for Clostridium botulinum type $\mathrm{C}$ toksin. (Susceptibility of mink to Clostridium botulinum type C toxin). Nord. Vet.-Med. 1968, 20, 313-318.

Vallée, A., A. Kreguer \& A. Eyquem: Botulisme canin: Première souche isolé en France. (Botulism in dogs. The first case reported in France). Bull. Acad. vét. Fr. 1956, 29, 419—423.

Yndestad, M. \& G. Loftsgård: Susceptibility of mink to Clostridium botulinum type $\mathrm{C}$ toxin. Acta vet. scand. 1970, 11, 594-599.

\section{SAMMENDRAG}

Revs mottagelighet for botulinumtoksin type Cog $E$.

Det er utført fors $\varnothing \mathrm{k}$ for å bestemme hvor mottagelig rev er overfor Clostridium botulinum type $\mathrm{C}$ og $\mathrm{E}$ toksin. Doser på 5 mill. MLD type $\mathrm{C}$ toksin blandet $\mathrm{i}$ fóret fremkalte ikke symptomer på hverken hvalper eller voksne rever. Mengder på 300.000 MLD og 750.000 MLD gitt subcutant forårsaket død på henholdsvis alle hvalper og voksne rever. Når det gjaldt type $\mathrm{E}$ toksin kunne en ikke få frem symptomer på botulisme ved doser på 1 mill. MLD gitt i fóret. Subcutan applikasjon av 5.000 MLD og 10.000 MLD gitt til henholdsvis hvalper og voksne drepte alle dyrene.

Det synes således som rev er meget resistent overfor både type $\mathrm{C}$ og E Clostridium botulinum toksin ved oral applikasjon. Ved subcutan injeksjon er følsomheten $60-70$ ganger st $\varnothing$ rre for type $E$ enn for type C toksin.

(Received November 29, 1976).

Reprints may be requested from: Magne Yndestad, Department of Food Hygiene, Veterinary College of Norway, P. O. Box 8146, Oslo Dep., Oslo 1, Norway. 